\title{
Knowledge Attitude and Practices towards COVID-19 among Orthodontic Patients of KVG Dental College Sullia Dakshina Kannada District, During Rapid Rise Period of the COVID-19 Outbreak
}

\author{
Sharath Kumar Shetty ${ }^{1}$, Sagar Desai ${ }^{2 *}$, Mahesh Kumar $Y^{3}$, Vijayananda K Madhur ${ }^{4}$, Brigit Alphonsa ${ }^{4}$
}

${ }^{1}$ Professor \& HOD, Department of Orthodontics and Dentofacial Orthopaedics, K. V. G. Dental College and Hospital, Sullia, Karnataka, India

${ }^{2}$ Post Graduate Student, Department of Orthodontics and Dentofacial Orthopaedics, K. V. G. Dental College and Hospital, Sullia, Karnataka, India

${ }^{3}$ Professor, Department of Orthodontics and Dentofacial Orthopaedics, K. V. G. Dental College and Hospital, Sullia, Karnataka, India

${ }^{4}$ Reader, Department of Orthodontics and Dentofacial Orthopaedics, K. V. G. Dental College and Hospital, Sullia, Karnataka, India

\begin{abstract}
DOI: $\underline{10.36347 / \text { sjds.2020.v07i12.006 }}$
| Received: 11.12.2020 | Accepted: 24.12.2020 | Published: 30.12.2020
\end{abstract}

*Corresponding author: Sagar Desai

Abstract

Original Research Article

In India, an array of measures have been adopted to control the rapid spread of the COVID-19 epidemic. Such general population control measures could significantly influence perception, knowledge, attitudes, and practices (KAP) towards COVID-19. Here, we assessed KAP towards COVID-19 during the rapid rise period of the outbreak. Onlinebased cross-sectional study conducted from 15th May to July 31st, 2020, involving patients of on-going orthodontic treatment in KVG Dental college Sullia, and in an age group of 15-40 yrs via social media. After consenting, participants completed an online survey assessing socio-demographic variables and KAP towards COVID-19. Of the present survey participants, $32 \%$ were males and $68 \%$ were females, $50.7 \%$ were from rural residents, $1.3 \%$ from semirural, $42.7 \%$ from semi urban and $5.3 \%$ from urban residents actively participated in the study. 53.33\% participants were from Karnataka and $46.66 \%$ were from Kerala state. The survey revealed that $90.77 \%$ of participants had more accurate knowledge, $93.99 \%$ had more positive attitudes, and $82 \%$ had more frequent practices regarding COVID-19 prevention. Overall (96\%) participants wore a face mask in crowded places showing their awareness. Therefore, development of effective health education programs that incorporate considerations of KAP-modifying factors is needed.

Keywords: KAP, COVID 19 India, Orthodontic Patients COVID -19.

Copyright $\odot 2020$ The Author(s): This is an open-access article distributed under the terms of the Creative Commons Attribution 4.0 International License (CC BY-NC 4.0) which permits unrestricted use, distribution, and reproduction in any medium for non-commercial use provided the original author and source are credited.

\section{INTRODUCTION}

Coronavirus disease 2019 (COVID-19) is an acute respiratory disease caused by a novel coronavirus and was first detected in December 2019 in Wuhan, China [1]. Since then, it has rapidly spread to more than 200 countries and has been declared a global pandemic by the World Health Organisation (WHO). As of 31 July 2020, there are more than 17.1 million positive COVID-19 cases recorded with 668,910 deaths globally [2]. India's response to the COVID-19 pandemic is one of the most stringent in the world, and it scored a perfect 100 on the "Oxford COVID-19 Government Response Tracker (OxCGRT)" that compares various government responses to the coronavirus outbreak worldwide [3]. The initial rise in the numbers of cases was at a low rate in the country, which may be attributed to several government policies and implementation of a nation-wide lockdown at an early stage of the pandemic. As the second-most populous country, however, the eventual rapid rise to being the second-highest infected country in the world could not be restrained.

The COVID-19 pandemic is at its peak in India and the fight is still continuing. While controlling the movement of people can limit the spread, empowering citizens with the right information and encouraging their strict adherence to government advisories play a crucial role in outbreak management. Data from the SARS outbreak in 2003 suggest that knowledge and attitudes towards infectious diseases are usually associated with a high level of panic among the population, which can further complicate measures to prevent the spread of the disease [4].

Though the entire healthcare system is focused on prevention and containment of COVID-19 infection, timely diagnosis and treatment of other diseases are equally important. Patients seeking healthcare during this lockdown period have a higher risk of exposure, thus awareness of ways to mitigate infection likelihood 
is important. Poor knowledge, attitude, and practice (KAP) patterns among these patients might reflect the danger of possible high transmission and the need for awareness campaigns. In order to facilitate outbreak management and assess patient readiness to accept behavioural changes, this study aimed to analyse the KAP among on-going orthodontic patients who presented personally and who contacted via phone to Orthodontic department of KVG Dental college and hospitals sullia, during the lockdown for their orthodontic needs and advices .

\section{METHOD}

\section{Participation and Procedure}

A cross-sectional and anonymous online patient-based survey was conducted among individuals aged 15-40 years. The survey was conducted from May $15^{\text {th }}$ to July $31^{\text {st }}$, 2020. A semi-structured questionnaire was designed for the Google survey tool (Google Forms), and the generated link was shared to participants on social media (i.e., Facebook, WhatsApp). The link was also shared personally to the contact list of patients undergoing orthodontic treatment in $\mathrm{KVG}$ dental college Sullia. The investigator's decision to collect the data using online approaches was predicated on maintaining social distance during the strict covid-19 outbreak. The inclusion criteria in the study were being Orthodontic patients of KVG Dental
College sullia, having internet access, and willing to voluntary participation.

\section{Measures}

A Semi structured and self-reported questionnaire containing questions regarding sociodemographics, knowledge, attitude, and practices. Socio-demographic information was collected, including gender, age, residential details and state in which they reside.

To assess the level of knowledge, attitude, and practice of the respondents, a total of 16 questions (including 12 for knowledge, 2 for attitude, and 2 for practice) were included. The Knowledge, Attitude, and Practices questionnaire was designed based on the extensive literature review published on COVID-19 [58]. And the Performa for questionnaire is as follows, Email address -

Demographic data

Gender---Male/Female

State--

Age--

Location of Residence --Urban

--Semirural

--Rural

Knowledge, attitude, and practice

\begin{tabular}{|c|c|c|}
\hline & Questions & Options \\
\hline & Knowledge & \\
\hline K1 & The main clinical symptoms of COVID-19 are fever, fatigue, dry cough, and myalgia. & $\begin{array}{l}\text { True } \\
\text { False } \\
\text { I don't know }\end{array}$ \\
\hline $\mathbf{K 2}$ & $\begin{array}{l}\text { Unlike the common cold, stuffy nose, runny nose, and sneezing are less common in persons } \\
\text { infected with the COVID-19 virus. }\end{array}$ & $\begin{array}{l}\text { True } \\
\text { False } \\
\text { I don't know }\end{array}$ \\
\hline K3 & $\begin{array}{l}\text { There currently is no effective cure for COVID-19, but early symptomatic and supportive treatment } \\
\text { can help most patients recover from the infection. }\end{array}$ & $\begin{array}{l}\text { True } \\
\text { False } \\
\text { I don't know }\end{array}$ \\
\hline K4 & $\begin{array}{l}\text { Not all persons with COVID-19 will develop to severe cases. Only those who are elderly, have } \\
\text { chronic illnesses, and are obese are more likely to be severe cases. }\end{array}$ & $\begin{array}{l}\text { True } \\
\text { False } \\
\text { I don't know }\end{array}$ \\
\hline K5 & Eating or contacting wild animals would result in the infection by the COVID-19 virus. & $\begin{array}{l}\text { True } \\
\text { False } \\
\text { I don't know }\end{array}$ \\
\hline K6 & Persons with COVID-19 virus cannot infect to others when a fever is not present. & $\begin{array}{l}\text { True } \\
\text { False } \\
\text { I don't know }\end{array}$ \\
\hline K7 & The COVID-19 virus spreads via respiratory droplets of infected individuals. & $\begin{array}{l}\text { True } \\
\text { False } \\
\text { I don't know }\end{array}$ \\
\hline K8 & Ordinary residents can wear general cloth masks to prevent the infection by the COVID-19 virus. & $\begin{array}{l}\text { True } \\
\text { False } \\
\text { I don't know }\end{array}$ \\
\hline K9 & $\begin{array}{l}\text { It is not necessary for children and young adults to take measures to prevent the infection by the } \\
\text { COVID-19 virus. }\end{array}$ & $\begin{array}{l}\text { True } \\
\text { False } \\
\text { I don't know }\end{array}$ \\
\hline K10 & $\begin{array}{l}\text { To prevent the infection by COVID-19, individuals should avoid going to crowded places such as } \\
\text { bus ,train stations and avoid taking public transportations. }\end{array}$ & $\begin{array}{l}\text { True } \\
\text { False } \\
\text { I don't know }\end{array}$ \\
\hline K11 & $\begin{array}{l}\text { Isolation and treatment of people who are infected with the COVID-19 virus are effective ways to } \\
\text { reduce the spread of the virus. }\end{array}$ & $\begin{array}{l}\text { True } \\
\text { False } \\
\text { I don't know }\end{array}$ \\
\hline
\end{tabular}




\begin{tabular}{|c|c|c|}
\hline K12 & $\begin{array}{l}\text { People who have contact with someone infected with the COVID-19 virus should be immediately } \\
\text { isolated in a proper place. In general, the observation period is } 14 \text { days. }\end{array}$ & $\begin{array}{l}\text { True } \\
\text { False } \\
\text { I don't know }\end{array}$ \\
\hline & Attitudes & \\
\hline A1 & Do you agree that COVID-19 will finally be successfully controlled? & $\begin{array}{l}\text { Agree } \\
\text { Disagree } \\
\text { I don't know }\end{array}$ \\
\hline $\mathbf{A 2}$ & Do you have confidence that INDIA can win the battle against the COVID-19 virus? & $\begin{array}{l}\text { Yes } \\
\text { NO }\end{array}$ \\
\hline & Practices & \\
\hline P1 & In recent days, have you gone to any crowded place? Yes, no ? & $\begin{array}{l}\text { Yes } \\
\text { NO }\end{array}$ \\
\hline $\mathbf{P 2}$ & In recent days, have you worn a mask when leaving home? & $\begin{array}{l}\text { Yes } \\
\text { NO }\end{array}$ \\
\hline
\end{tabular}

\section{RESULTS}

A total of 75 respondents were included in the final analysis, of which, $32 \%$ were male and $68 \%$ were females, $50.7 \%$ were from rural residents, $1.3 \%$ from semirural, $42.7 \%$ from semi urban and $5.3 \%$ from urban residents actively participated in the study. $53.33 \%$ participants were from Karnataka and $46.66 \%$ were from Kerala state (Table 1, 2, $3 \&$ 4, Graph 1, 2, 3 $\& 4)$. The knowledge of the participants regarding the symptoms is good out of 75 participants $90.66 \%$ of them have answered correctly and very few of them have answered incorrectly and this signifies that the knowledge regarding the symptoms of the participants is very good (Table 5, 6 and Graph 5, 6).

The knowledge about cure and treatment of COVID 19 among the participants was good too; about $96.66 \%$ of the people have answered the questions correctly. And about $3.34 \%$ of people have answered poorly and very few of them have no knowledge about the same (Table 7 and Graph 7). The Knowledge regarding severity and vulnerability in elderly age, $94.66 \%$ of people has answered correctly and $2.44 \%$ of people have answered poorly and very few of them don't about the question. The knowledge about eating and contacting animals, $77 \%$ of people answered correctly and rest of them answered poorly (Table 9 and Graph 9). Knowledge regarding the spread of infection, $88.66 \%$ people have good knowledge and very less percentage of people have answered poorly and some of them have no knowledge about the same (Table 10, 11 and Graph 10,11) knowledge regarding type of masks $89.33 \%$ people answered correctly (Table 12 and Graph 12). Knowledge about vulnerability among children and young, $85 \%$ of people have answered correctly and $14.66 \%$ of the people answered incorrectly (Table 13 and Graph 13). Knowledge regarding spread of infection in crowded places, $97.33 \%$ people answered correctly and $2.66 \%$ of the people answered poorly (Table 14 and Graph 14). Knowledge regarding Isolation after contact of infection, $98.66 \%$ of people have answered correctly and $1.33 \%$ of people have answered incorrectly (Table 15, 16 and Graph 16). Over $90.77 \%$ of participants have answered the questions very correctly which signifies knowledge of the participants is very good.
The Attitude of the participants regarding control of infection was also very good. Around $89.33 \%$ of people answered correctly about the control of the infection and very few people around $6.66 \%$ of people answered incorrectly and some people don't know about the answer. Around $98.66 \%$ of the people have confidence on Indian governance that it will win the battle against the COVID-19. Overall Attitude of the participants was very good (Table 17, 18 and Graph 17, 18).

The practice of the participants regarding crowded places and social distancing, 68\% people preferred to visit the crowded places for their day today activities and $96 \%$ of people answered correctly regarding use of mask before going out from home. Overall $96 \%$ of participants answered correctly regarding the use of mask before going out. Which clearly signifies that people have adequately good practices in their day today route in (Table 19, 20 \& Graph 19, 20).

The findings suggest that although patients generally have an acceptable level of knowledge on COVID-19 and tend to be positive in their outlook on overcoming the pandemic, innovative awareness and preventive measures are needed considering the number of study population who had lower KAP scores. Considering the possibility of a prolonged pandemic situation and possible second wave, consistent reinforcement of preventive guidelines from the government health authorities is essential to maintain strict adherence by the general public.

Table-1: Age Distibution of Study Population

\begin{tabular}{|l|l|l|}
\hline Age Distribution & Number Of Frequency & $\mathbf{\%}$ \\
\hline $15-20$ & 29 & 38.66 \\
\hline $21-25$ & 32 & 42.66 \\
\hline $26-30$ & 7 & 9.33 \\
\hline $31-35$ & 2 & 2.66 \\
\hline $36-40$ & 2 & 2.66 \\
\hline$>40$ & 3 & 4.0 \\
\hline Total & 75 & 100.0 \\
\hline
\end{tabular}




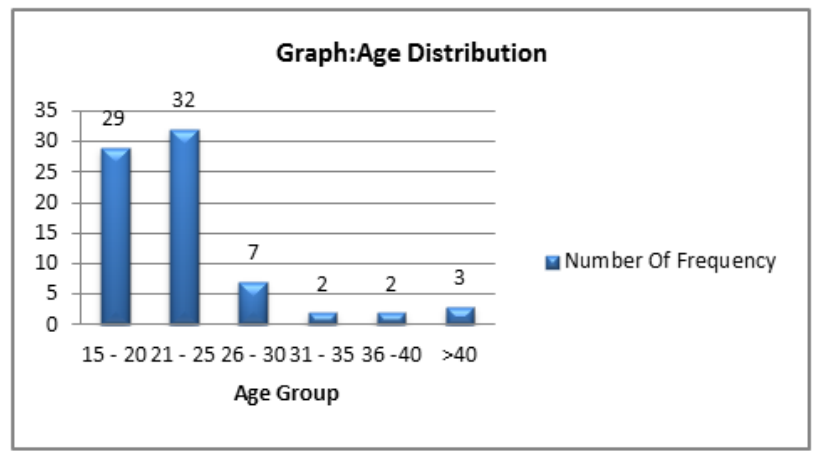

Graph-1: Age Distibution of Study Population

Table-2: Gender Distibution of Study Population

\begin{tabular}{|l|l|l|}
\hline Gender & Number Of Frequency & \% \\
\hline Male & 24 & 32.0 \\
\hline Female & 51 & 68.0 \\
\hline Total & 75 & 100.0 \\
\hline
\end{tabular}

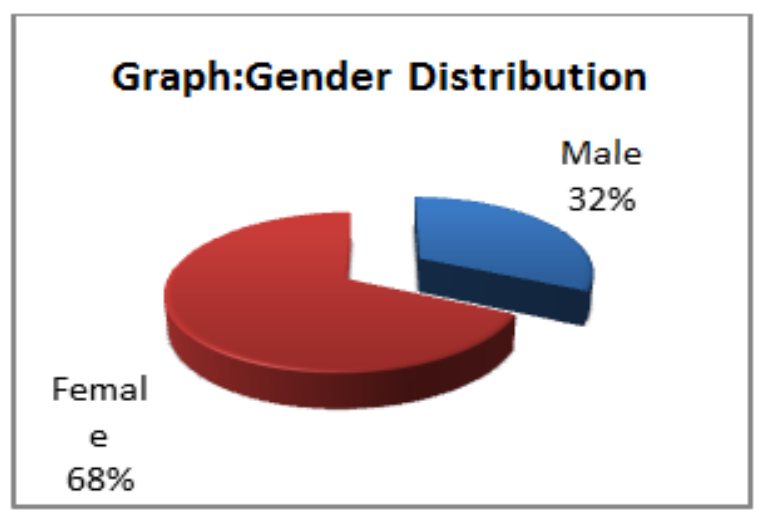

Graph-2: Gender Distibution of Study Population

Table-3: Distribution of Cases According To the Location of Residence

\begin{tabular}{|l|l|l|}
\hline $\begin{array}{l}\text { Location of } \\
\text { Residence }\end{array}$ & $\begin{array}{l}\text { Number of } \\
\text { Frequency }\end{array}$ & \% \\
\hline Rural & 38 & 50.7 \\
\hline Semi Rural & 1 & 1.3 \\
\hline Semi Urban & 32 & 42.7 \\
\hline Urban & 4 & 5.3 \\
\hline Total & 75 & 100.0 \\
\hline
\end{tabular}

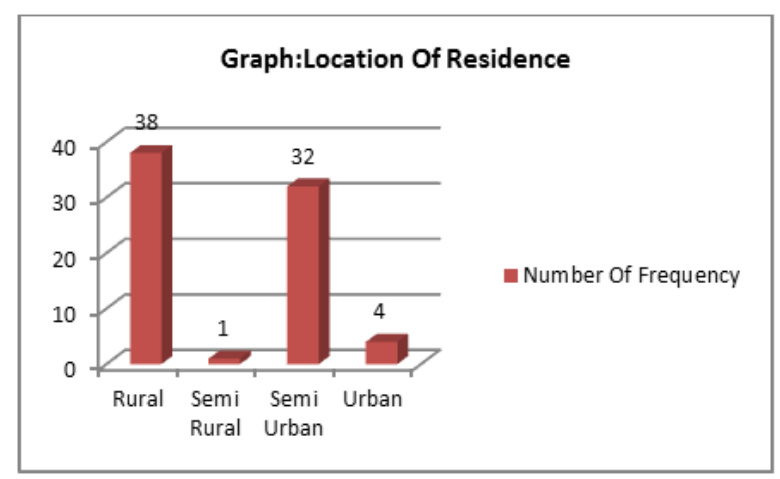

Graph-3: Distribution of Cases According To the Location of Residence
Table-4: Distribution of Cases According To the State Response

\begin{tabular}{|l|l|l|}
\hline State & Number Of Frequency & \% \\
\hline Karnataka & 40 & 53.33 \\
\hline Kerala & 35 & 46.66 \\
\hline Total & 75 & 100.0 \\
\hline
\end{tabular}

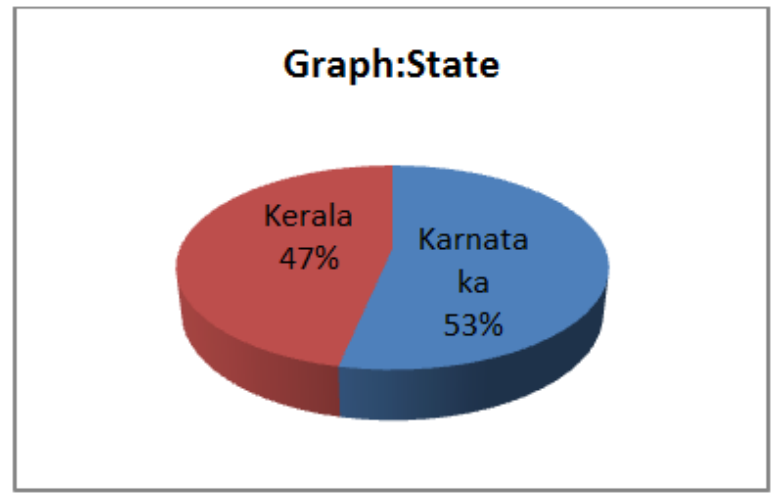

Graph-4: Distribution of Cases According To the State Response

Table-5: K1). The main clinical symptoms of COVID-19 are fever, fatigue, dry cough, and myalgia

\begin{tabular}{|l|l|l|}
\hline K1 & Number Of Frequency & $\%$ \\
\hline True & 74 & 98.66 \\
\hline False & 1 & 1.33 \\
\hline Total & 75 & 100.0 \\
\hline
\end{tabular}

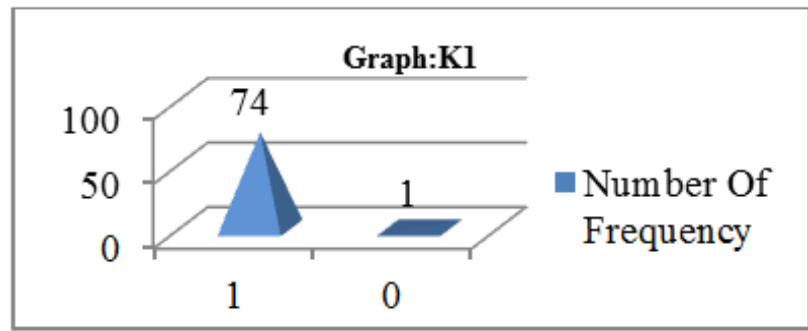

Graph-5: K1). The main clinical symptoms of COVID-19 are fever, fatigue, dry cough, and myalgia

Table-6: K2). Unlike the common cold, stuffy nose, runny nose, and sneezing are less common in persons infected with the COVID-19 virus

\begin{tabular}{|l|l|l|}
\hline K2 & Number of Frequency & $\%$ \\
\hline False & 62 & 82.66 \\
\hline True & 10 & 13.33 \\
\hline I Don't Know & 3 & 4.0 \\
\hline Total & 75 & 100.0 \\
\hline
\end{tabular}




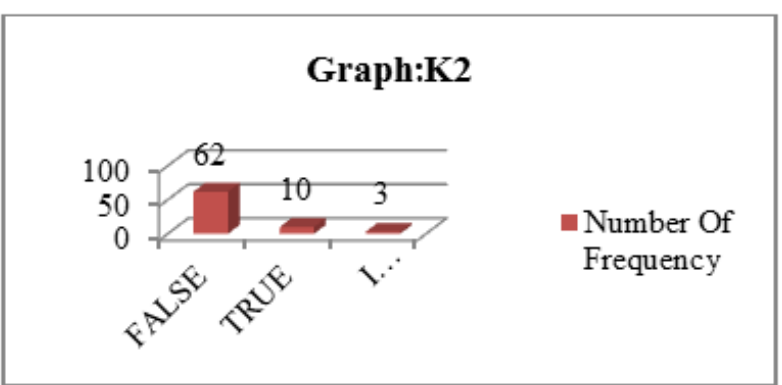

Graph-6: K2). Unlike the common cold, stuffy nose, runny nose, and sneezing are less common in persons infected with the COVID-19 virus

Table-7: K3.Here currently is no effective cure for COVID-19, but early symptomatic and supportive treatment can help most patients recover from the infection

\begin{tabular}{|l|l|l|}
\hline K3 & Number Of Frequency & \% \\
\hline True & 74 & 98.66 \\
\hline False & 1 & 1.33 \\
\hline Total & 75 & 100.0 \\
\hline
\end{tabular}

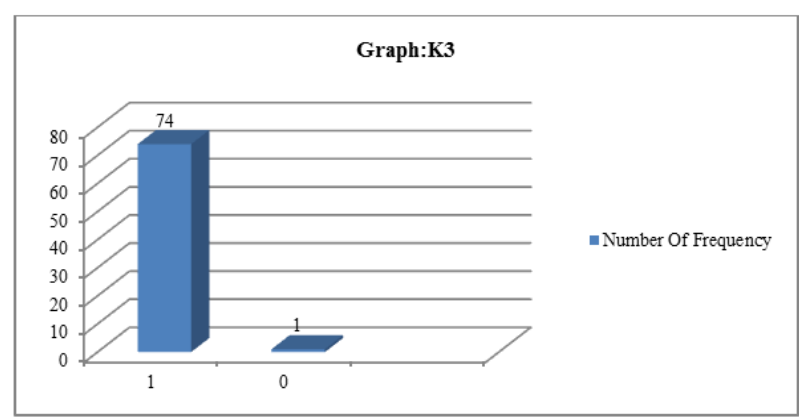

Graph-7: K3. Here currently is no effective cure for COVID-19, but early symptomatic and supportive treatment can help most patients recover from the infection

Table-8: K4). Not all persons with COVID-19 will develop to severe cases. Only those who are elderly, have chronic illnesses, and are obese are more likely to be severe cases

\begin{tabular}{|l|l|l|}
\hline K4 & Number Of Frequency & $\mathbf{\%}$ \\
\hline True & 71 & 94.66 \\
\hline False & 2 & 2.66 \\
\hline I Don't Know & 2 & 2.66 \\
\hline Total & 75 & 100.0 \\
\hline
\end{tabular}

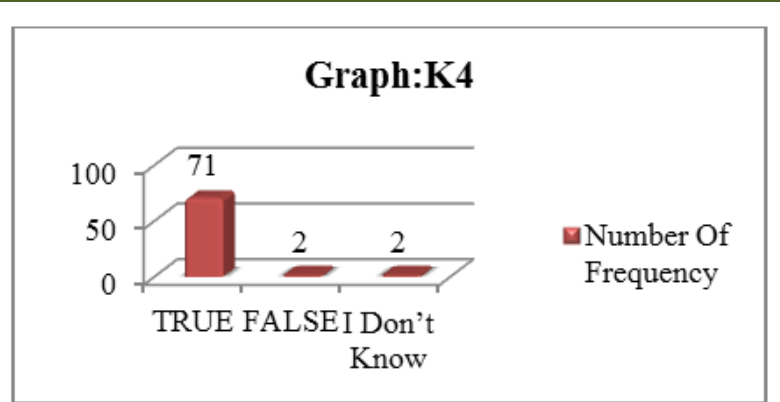

Graph-8: K4). Not all persons with COVID-19 will develop to severe cases. Only those who are elderly, have chronic illnesses, and are obese are more likely to be severe cases

Table-9: K5). Eating or contacting wild animals would result in the infection by the COVID-19 virus

\begin{tabular}{|l|l|l|}
\hline K5 & Number Of Frequency & \% \\
\hline True & 58 & 77.33 \\
\hline False & 12 & 16.0 \\
\hline I Don't Know & 5 & 6.66 \\
\hline Total & 75 & 100.0 \\
\hline
\end{tabular}

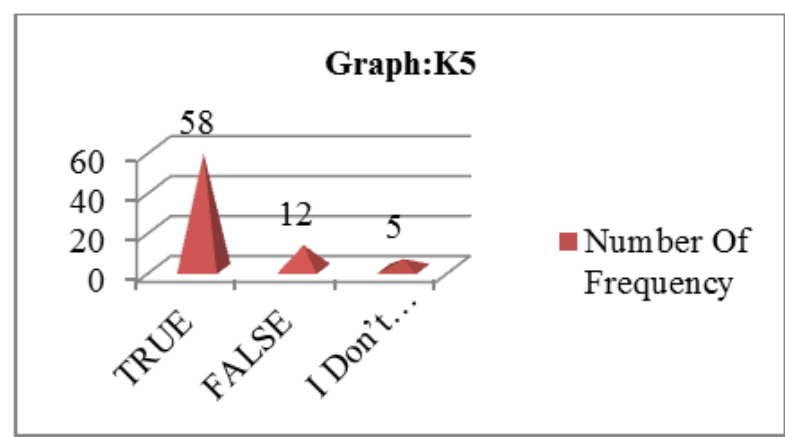

Graph-9: K5). Eating or contacting wild animals would result in the infection by the COVID-19 virus

Table-10: K6). Persons with COVID-19 virus cannot infect to others when a fever is not present

\begin{tabular}{|l|l|l|}
\hline K6 & Number Of Frequency & $\%$ \\
\hline True & 59 & 78.66 \\
\hline False & 13 & 17.33 \\
\hline I Don't Know & 3 & 4.0 \\
\hline Total & 75 & 100.0 \\
\hline
\end{tabular}

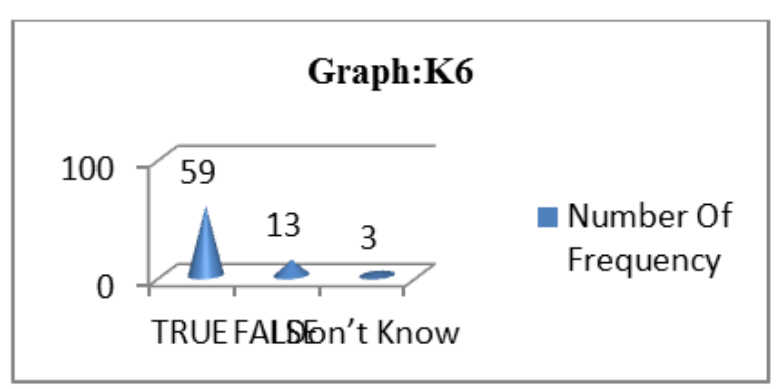

Graph-10: K6). Persons with COVID-19 virus cannot infect to others when a fever is not present 
Table-11: K7). The COVID-19 virus spreads via respiratory droplets of infected individuals

\begin{tabular}{|l|l|l|}
\hline K7 & Number Of Frequency & \% \\
\hline True & 74 & 98.66 \\
\hline False & 1 & 1.33 \\
\hline Total & 74 & 100.0 \\
\hline
\end{tabular}

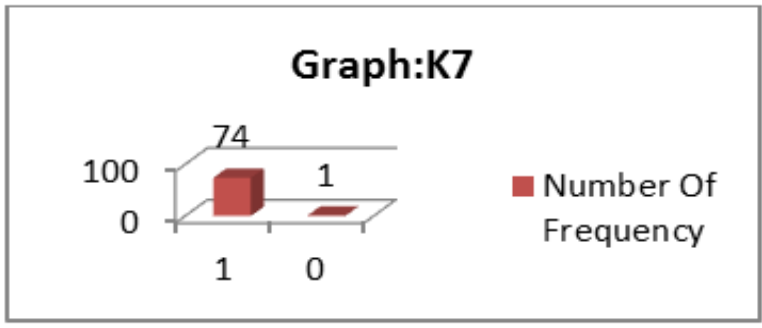

Graph-11: K7). The COVID-19 virus spreads via respiratory droplets of infected individuals

Table-12: K8). Ordinary residents can wear general cloth masks to prevent the infection by the COVID-

19 virus

\begin{tabular}{|l|l|l|}
\hline K8 & Number Of Frequency & \% \\
\hline True & 67 & 89.33 \\
\hline False & 5 & 6.66 \\
\hline I Don't Know & 3 & 4.0 \\
\hline Total & 75 & 100.0 \\
\hline
\end{tabular}

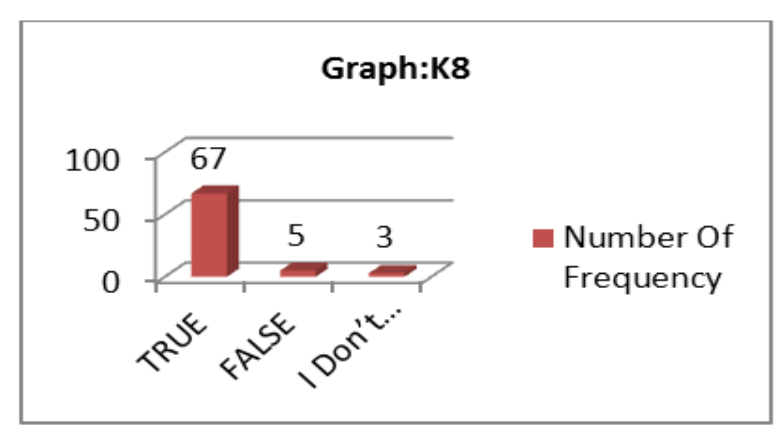

Graph-12: K8). Ordinary residents can wear general cloth masks to prevent the infection by the COVID19 virus

Table-13: K9). It is not necessary for children and young adults to take measures to prevent the infection by the COVID-19 virus

\begin{tabular}{|l|l|l|}
\hline K9 & Number Of Frequency & \% \\
\hline False & 64 & 85.33 \\
\hline True & 11 & 14.66 \\
\hline Total & 75 & 100.0 \\
\hline
\end{tabular}

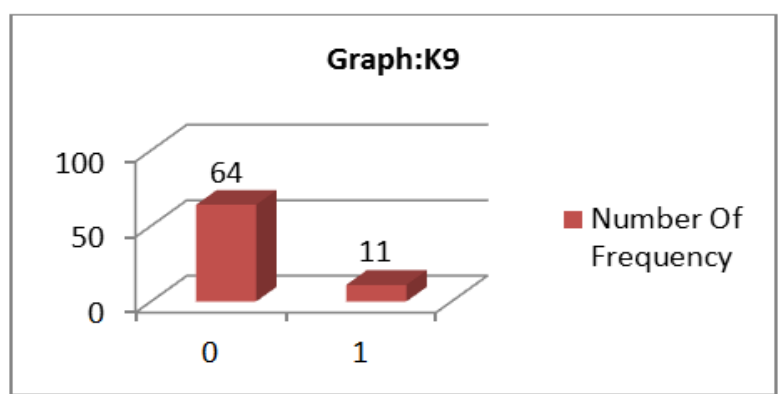

Graph-13: K9). It is not necessary for children and young adults to take measures to prevent the infection by the COVID-19 virus

Table-14: K10). To prevent the infection by COVID19, individuals should avoid going to crowded places such as bus, train stations and avoid taking public transportations

\begin{tabular}{|l|l|l|}
\hline K10 & Number Of Frequency & \% \\
\hline True & 73 & 97.33 \\
\hline False & 2 & 2.66 \\
\hline Total & 75 & 100.0 \\
\hline
\end{tabular}

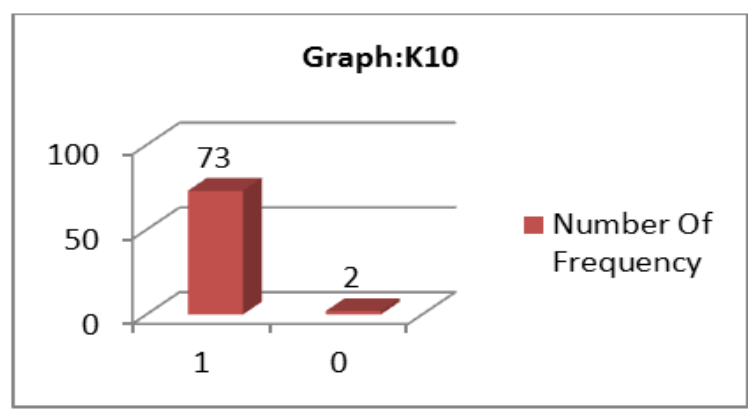

Graph-14: K10). To prevent the infection by

COVID-19, individuals should avoid going to crowded places such as bus, train stations and avoid taking public transportations

Table-15: K11). Isolation and treatment of people who are infected with the COVID-19 virus are effective ways to reduce the spread of the virus

\begin{tabular}{|l|l|l|}
\hline K11 & Number Of Frequency & \% \\
\hline True & 74 & 98.66 \\
\hline I Don't Know & 1 & 1.33 \\
\hline Total & 75 & 100.0 \\
\hline
\end{tabular}

Table-16:K12). People who have contact with someone infected with the COVID-19 virus should be immediately isolated in a proper place. In general, the observation periodis 14days

\begin{tabular}{|l|l|l|}
\hline K12 & Number Of Frequency & \% \\
\hline True & 74 & 98.66 \\
\hline I Don't Know & 1 & 1.33 \\
\hline Total & 75 & 100.0 \\
\hline
\end{tabular}




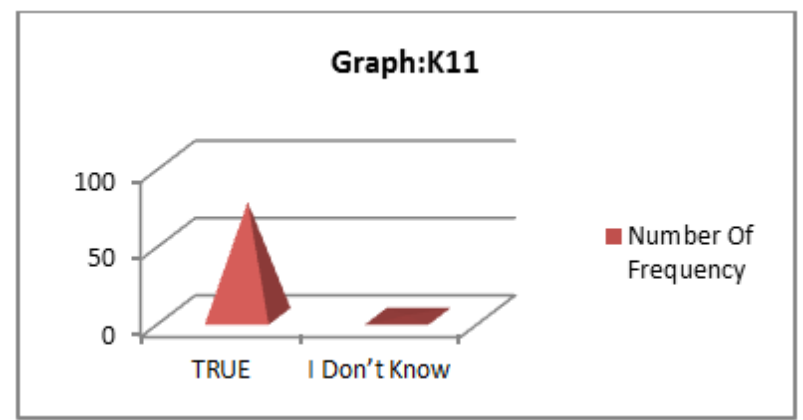

Graph-16: K12). People who have contact with someone infected with the COVID-19 virus should be immediately isolated in a proper place. In general, the observation periodis 14days

Table-17: A1). Do you agree that COVID-19 will finally be successfully controlled?

\begin{tabular}{|l|l|l|}
\hline A1 & Number Of Frequency & \% \\
\hline Agree & 67 & 89.33 \\
\hline Disagree & 5 & 6.66 \\
\hline I Don't Know & 3 & 4.0 \\
\hline Total & 75 & 100.0 \\
\hline
\end{tabular}

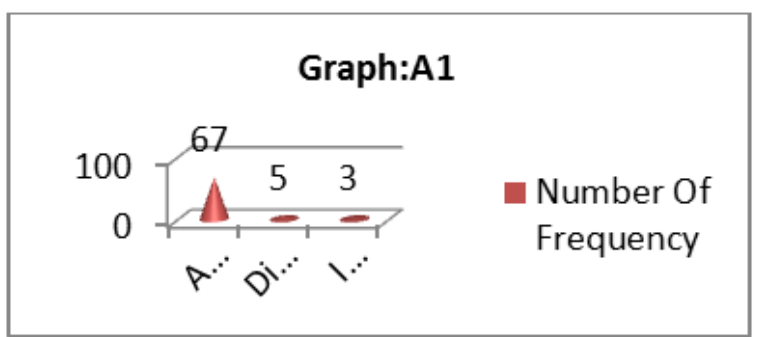

Graph-17: A1). Do you agree that COVID-19 will finally be successfully controlled?

Table-18: A2). Do you have confidence that INDIA can win the battle against the COVID-19 virus?

\begin{tabular}{|l|l|l|}
\hline A2 & Number Of Frequency & \% \\
\hline Yes & 74 & 98.66 \\
\hline No & 1 & 1.33 \\
\hline Total & 75 & 100.0 \\
\hline
\end{tabular}

\begin{tabular}{|c|} 
Graph:A2 \\
$\square$ Yes $\square$ No \\
$99 \%$
\end{tabular}

Graph-18: A2). Do you have confidence that INDIA can win the battle against the COVID-19 virus?

Table-19: P1). In recent days, have you gone to any crowded place? Yes, no?

\begin{tabular}{|l|l|l|}
\hline P1 & Number Of Frequency & $\%$ \\
\hline Yes & 51 & 68.0 \\
\hline No & 24 & 32.0 \\
\hline Total & 75 & 100.0 \\
\hline
\end{tabular}

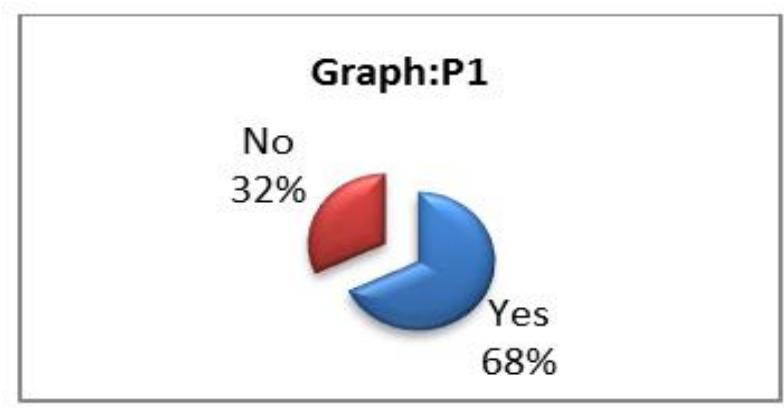

Graph-19: P1). In recent days, have you gone to any crowded place? Yes, no?

Table-20: P2). In recent days, have you worn a mask when leaving home?

\begin{tabular}{|l|l|l|}
\hline P2 & Number Of Frequency & \% \\
\hline Yes & 72 & 96.0 \\
\hline No & 3 & 4.0 \\
\hline Total & 75 & 100.0 \\
\hline
\end{tabular}

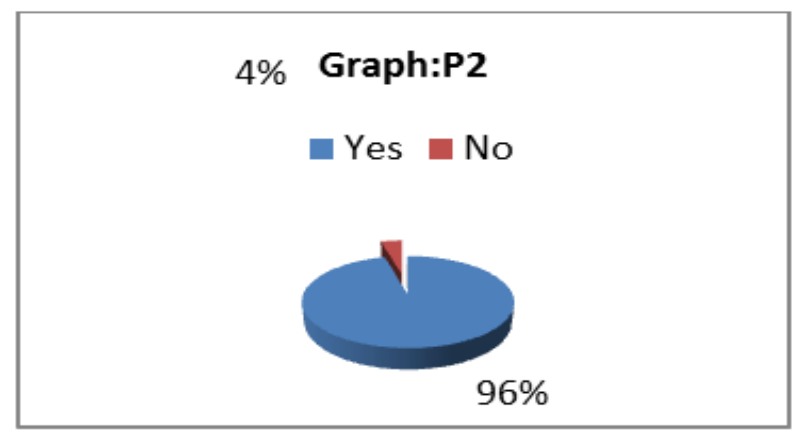

Graph-20: P2). In recent days, have you worn a mask when leaving home?

\section{DISCUSSION}

In the short time since it was first discovered in December 2019, the novel COVID19 virus has resulted, in an unprecedented and dynamic crisis. In view of the novelty of the disease and the uncertainties associated with its pathogenesis, the active participation of the population in the management of rapid spread is crucial. To date, limited data on the trends of knowledge, attitude, and practice (KAP) towards COVID 19 among patients has been known. Considering the multiple levels of exposure hazards that occur in a hospital during their treatment visits, understanding KAP among patients is valuable.

In our study, among the total 75 participants interviewed, majority $42.66 \%$ were between $21-25$ years of age, and $38.66 \%$ were from 15-20 years of age group indicating that they needed or wanted in-person orthodontic care most urgently during that period .Though the majority of the knowledge questions were answered correctly. Considering the high contagiousness associated with dental problems it is crucial that orthodontist encourage patients to take necessary precautionary measures to avoid spread. 
The present study found that a large majority of participants had a positive attitude towards overcoming COVID-19. Approximately 79\% of participants believed that the COVID-19 pandemic will be controlled in the near future in India. High levels of positive attitudes were also detected in the KAP study conducted in China [5] and Malaysia [10], which may reflect the swift action of local and national government organizations. Similarly, the authors of our study attribute the largely positive attitudes to the drastic measures taken by the Indian state governments in mitigating the spread of the virus via early lockdown and rapid measures to uplift healthcare facilities. About $99.6 \%$ of our study population had a good practice score, in the form of taking precautions, such as avoiding crowded places, regular hand washing, hand hygiene, wearing mask and social distancing. This indicates a general willingness for participants to make behavioural changes in the face of the COVID-19 pandemic.

The majority of studies conducted in other countries have indicated higher levels of COVID-19 knowledge among the general population $[5,10]$ and healthcare workers [7, 8]. Differences in measurement and scoring systems, however, prevent accurate comparisons of knowledge levels across these studies. Additionally, government-sponsored media may emphasize varying aspects of the disease in education campaigns, making it even more difficult to standardize KAP scores between studies. The multicentric nature of the sample, with a varied geographic population, will approximately simulate the KAP score of the general population. As a result, our data will assist health officials in determining the target groups for enhanced awareness campaigns. As previously mentioned, because of their prioritization of seeking care, our sample might represent a more healthconscious part of the population. Most of the questions answered from the questionnaire, as with any KAP study, are subjective and may not really represent patient activities, particularly if they are hoping to prevent a study administrator from disapproving habits that do not comply with current guidelines. Similarly, it is difficult to determine patient habits correctly since they are subject to the viewpoint of the client on correct use.

As discussed by Feng et al., [11] among people wearing masks, improper use, and neglecting to change disposable masks could actually jeopardize the protective effect and even increase the risk of infection. Consequently, patients who reported wearing masks may not be doing so in an optimally hygienic nature, thus the high practice scores in our study may not accurately represent the expected public health benefit if improper use was common. In light of these limitations, future studies can be aimed at focusing more on objective assessments to audit practice patterns of the public, offering a more multidimensional measure of the success of awareness and education efforts.

\section{LIMITATIONS}

Most of the questions answered from the questionnaire, as with any KAP study, are subjective and may not really represent patient activities, particularly if they are hoping to prevent a study administrator from disapproving habits that do not comply with current guidelines. Similarly, it is difficult to determine patient habits correctly since they are subject to the viewpoint of the client on correctuse.

Despite these challenges, our research shows $t$ hat KAP evaluations of the COVID19 pandemic of vulnerable populations require special efforts to resolve the gaps in the current approach to the study.

Fourth, to assess the degree of awareness, attit ude \& practices, we used a limited number of questions. Thus, in order to evaluate the actual degree of KAP in $\mathrm{t}$ he general population, additional analyses will be neces sary, using all aspects of KAP against COVID19. In ad dition, through focus group discussion and indepth inter views, the unstandardized and insufficient evaluation of attitudes and practices towards COVID should be devel oped and built as multi-dimensional steps.

\section{CONCLUSION}

In summary, a detailed analysis of the COVID 19 KAP among patients was possible in the current mul ticentre research. The results indicate that after the lockdown and during the rapid rise period of the COVID-19 outbreak, internet users in India displayed substantial differences in KAP regarding the pandemic. Our findings suggest the need for effective and tailored health education programs aimed at improving COVID19 knowledge, there by leading to more favourable attitudes and to implementation and maintenance of safe practices. Considering the possibility of a prolonged pandemic situation and possible second wave, consistent reinforcement of preventive guidelines from the government health authorities is essential to maintain strict adherence by the general public.

\section{REFERENCES}

1. Hui DS, Azhar EI, Madani TA, Ntoumi F, Kock R, Dar O, Ippolito G, Mchugh TD, Memish ZA, Drosten C, Zumla A. The continuing 2019-nCoV epidemic threat of novel coronaviruses to global health-The latest 2019 novel coronavirus outbreak in Wuhan, China. International Journal of Infectious Diseases. 2020 Feb 1;91:264-6.

2. World Health Organization. Coronavirus disease (COVID-19): Situation report-194. World Health Organization; $2020 . \quad$ Available from: https://www.who.int/docs/defaultsource/coronaviruse/situation-reports/20200801- 
covid-19-sitrep-194.pdf?sfvrsn=401287f3_2. [Last accessed on 2020 Oct 09].

3. Study reveals India's response to coronavirus most stringent [Internet]. cnbctv18.com. Available from: https://www.cnbctv18.com/healthcare/studyreveals-indias-response-to-coronavirus-moststringent-5666531.htm. [Last accessed on 2020 Oct 09]

4. Tao N. An analysis on reasons of SARS-induced psychological panic among students. J Anhui Inst Edu. 2003; 21:78-9.

5. Zhong BL, Luo W, Li HM, Zhang QQ, Liu XG, Li WT, Li Y. Knowledge, attitudes, and practices towards COVID-19 among Chinese residents during the rapid rise period of the COVID-19 outbreak: a quick online cross-sectional survey. International journal of biological sciences. 2020;16(10):1745-52.

6. Zhou M, Tang F, Wang Y, Nie H, Zhang L, You G, Zhang M. Knowledge, attitude and practice regarding COVID-19 among health care workers in Henan, China. Journal of Hospital Infection. 2020 Apr 9; 105:183-7.

7. Huynh G, Nguyen TNH, Tran VK, Vo KN, Vo VT, Pham LA. Knowledge and attitude toward COVID-19 among healthcare workers at District 2 Hospital, Ho Chi Minh City. Asian Pac J Trop Med. 2020; 6:260-5.

8. Olum R, Chekwech G, Wekha G, Nassozi DR, Bongomin F. Coronavirus Disease-2019: Knowledge, attitude, and practices of health care workers at makerere university teaching hospitals, Uganda. Front Public Health. 2020; 8:181.

9. Government of India, Ministry of Electronics and Information Technology. Aarogya Setu. Available from: https://www.mygov.in/aarogya-setu-app

10. Azlan AA, Hamzah MR, Sern TJ, Ayub SH, Mohamad E. Public knowledge, attitudes and practices towards COVID-19: A cross-sectional study in Malaysia. PLoS One. 2020; 15:e0233668.

11. Feng S, Shen C, Xia N, Song W, Fan M, Cowling BJ. Rational use of face masks in the COVID-19 pandemic. Lancet Respir Med. 2020; 8:434-6. 